\title{
Ornithology and integrated pest management: Red-winged Blackbirds Agelaius phoeniceus and corn
}

\author{
R. A. DOLBEER \\ US Department of Agriculture, Denver Wildlife Research Center, Plum Brook \\ Station, Sandusky, Ohio 44870, USA
}

\begin{abstract}
Red-winged Blackbirds Agelaius phoeniceus, the most abundant bird in North America, annually destroy over 360000 tonnes of field corn and substantial amounts of sweet corn. This loss, representing $<1 \%$ of North American corn production, is localized within $8 \mathrm{~km}$ of wetlands where Red-winged Blackbirds roost in late summer. Red-winged Blackbirds are often initially attracted to corn fields to feed on insect pests during the 2-3 week period between silking and kernel development. An ideal resolution of the conflict between corn farmers and Red-winged Blackbirds is to couple the birds' beneficial feeding habits in silking-stage corn with management techniques to reduce subsequent damage to kernels. Once birds switch from feeding on insects to feeding on corn, protective measures to reduce damage are more critical in the early (milk) stages of kernel development than later because the damage potential is much higher at this time. Birds must eat three times more kernels at 20 days after silking than at 40 days in order to receive the same corn biomass. The use of bird-resistant cultivars of corn, the deployment of frightening devices during the critical damage period, and the provision of alternative feeding sites are important components of an integrated management programme. The goal is to accommodate Red-winged Blackbirds as a part of the wetland-agricultural complex in North America.
\end{abstract}

In the $1800 \mathrm{~s}$ much of the original hardwood forest was cleared from the eastern and Great Lakes region of North America and replaced by agricultural crops. These land-use changes, while precipitating the demise of certain avian species such as the Passenger Pigeon Ectopistes migratorius (Schorger 1973), permitted expansion for populations of other avian species. The Red-winged Blackbird Agelaius phoeniceus, Common Grackle Quiscalus quiscula, and Brown-headed Cowbird Molothrus ater, were especially adapted to the open agricultural land that replaced the forests. In addition, the European Starling Sturnus vulgaris, introduced in 1890, was also welladapted to this environment and its population expanded rapidly. These four species, which often join together in large autumn and winter roosts, are the most abundant group of birds in North America today. The combined overwintering population is at least 500 million birds (Meanley \& Webb 1965, Meanley \& Royall 1976).

Of these four species, the Red-winged Blackbird is the most numerous and widespread (Dolbeer \& Stehn 1983). Because Red-winged Blackbirds associate closely with agriculture, they have long conflicted with man's activities, especially the growing of corn (maize) Zea mays. Depredations by Red-winged Blackbirds on ripening field corn presently represent the greatest economic loss by birds to any North American crop, over 360,000 tonnes annually (Tyler \& Kannenberg 1980, Weatherhead et al. 1982, Besser \& Brady 1986). Substantial loss is also reported for sweet corn in localized areas (Dolbeer et al. 1986a). Economic loss can be particularly severe for sweet corn because even slight damage can render ears unsaleable on the fresh produce markets. Depredation problems, besides their economic impact, have generated opposition within agricultural communities to certain environmental laws (Stone et al. 1984) and conservation programmes such as wetland preservation (Anon. 1983, Kleingartner 1989). 
It is important to recognize, however, that these overall losses, although impressive, are not of national concern since they represent $<1 \%$ of the total corn production in North America. Blackbirds are primarily of concern in localized areas within $8 \mathrm{~km}$ of late-summer wetland roost sites where corn yield losses of $5-15 \%$ are common. In addition, these same abundant birds may play beneficial roles in agricultural and natural ecosystems. For example, Red-winged Blackbirds consume large quantities of insect pests in corn and other crops, especially rootworm beetles Diabrotica longicornis, European corn borers Ostrinia nubilalis and corn earworms Heliothis zea (Mott \& Stone 1973, Bendell et al. 1981, Bendell \& Weatherhead 1982, McNicol et al. 1982, Bollinger \& Caslick 1985a). Red-winged Blackbirds, prey themselves to a variety of vertebrate predators, may buffer predation on other birds, including nesting waterfowl (Dolbeer 1980). Finally, it should be noted that Redwinged Blackbirds are an international migrant given some legal protection in the USA under the Migratory Bird Treaty Act.

This paper describes attempts to reduce blackbird damage to corn, based on the principles of integrated pest management, while maintaining the birds' beneficial attributes. Three components of Red-winged Blackbird and corn biology are considered: (i) population ecology of Red-winged Blackbirds in relation to corn maturation in late summer, (ii) feeding patterns of Red-winged Blackbirds in relation to corn maturation in late summer, and (iii) the use of cultivars of corn resistant to birds and other cultural and frightening techniques to reduce damage.

\section{Population ecology of Red-winged Blackbirds}

The continental population of Red-winged Blackbirds, perhaps 165 million birds at the start of the nesting season in April, doubles to over 350 million birds by early July when most young have fledged (Dolbeer et al. 1976, Meanley and Royall 1976). At this time, Red-winged Blackbirds begin concentrating in wetland roosts containing up to several million birds, usually within $200 \mathrm{~km}$ of their nesting localities (Dolbeer 1982). During the day these birds forage away from their roosts, some up to at least $18 \mathrm{~km}$ although most within $10 \mathrm{~km}$ (Martin 1977). Red-winged Blackbirds undergo a complete moult during July-September. The additional energy demands from moulting (Wiens \& Dyer 1975) coincide with peak numbers of birds at the time the corn crop is ripening. Economically significant damage to corn (i.e. $>5 \%$ yield loss) usually occurs only within $8 \mathrm{~km}$ of these late-summer roosts (Dolbeer 1980, Bollinger \& Caslick 1985b). During October-November, after the corn is harvested, Red-winged Blackbirds migrate to the southern United States for the winter (Dolbeer 1982). Waste corn in harvested corn fields is an important food for Redwinged Blackbirds from winter (White et al. 1985) to early summer (Clark et al. 1986).

Environmentally safe reduction of populations of Red-winged Blackbirds causing late-summer damage to corn and other crops has generally not proved feasible, either from a population dynamics perspective (Dolbeer et al. 1976, Dolbeer 1986), or in practice (Weatherhead 1982). Given the localized nature of the damage, the adaptations of Red-winged Blackbirds to the agricultural environment, and the beneficial attributes and legal status of these birds, population reduction as a routine management action, even if feasible, might not be desirable anyway. For these reasons, most research has focused on non-lethal approaches to reducing damage, although it is recognized that selected reductions of populations causing unusually large losses might be a desirable component of an integrated management programme if a safe, practical means to achieve these reductions were available. 


\section{Red-winged Blackbird feeding in relation to corn maturation}

Corn is typically planted in early May and ear development begins about 60 days later when the pistillate flowers, with elongated styles commonly referred to as silks, form in the leaf axils. About 15 days after silking (DAS), the ears have developed to the point where kernels are in the milk stage and first vulnerable to damage by birds. Sweet corn ears are usually harvested from 16 to 20 DAS, when the immature kernels still contain $70-80 \%$ water, so this crop is vulnerable to bird damage for only a few days. Field corn is allowed to mature before harvest; thus the crop is vulnerable to loss for several more weeks as the kernels, accumulating biomass, go through the dough and dent stages of development (Fig. 1). Water content of field corn kernels is usually $<20 \%$ at harvest.

\section{Feeding during silking period}

Red-winged Blackbirds are commonly observed in corn fields during the 2- to 3week period between silking and initial kernel development (hereafter referred to as silking period). No ripening corn is available in the fields for consumption at this time but insects are often abundant. In particular, rootworm beetles, a serious insect pest in the midwestern USA, are sometimes numerous on the silks, leaves and tassels of corn plants.

To test the hypothesis that Red-winged Blackbirds are initially attracted to corn fields in the silking period to feed on insects, Stickley \& Ingram (1976) and Woronecki et al. (1981) compared bird activity in sweet corn fields either treated with insecticide during the silking period or left untreated. Insecticide-treated fields were less attractive to Red-winged Blackbirds during the silking period than were

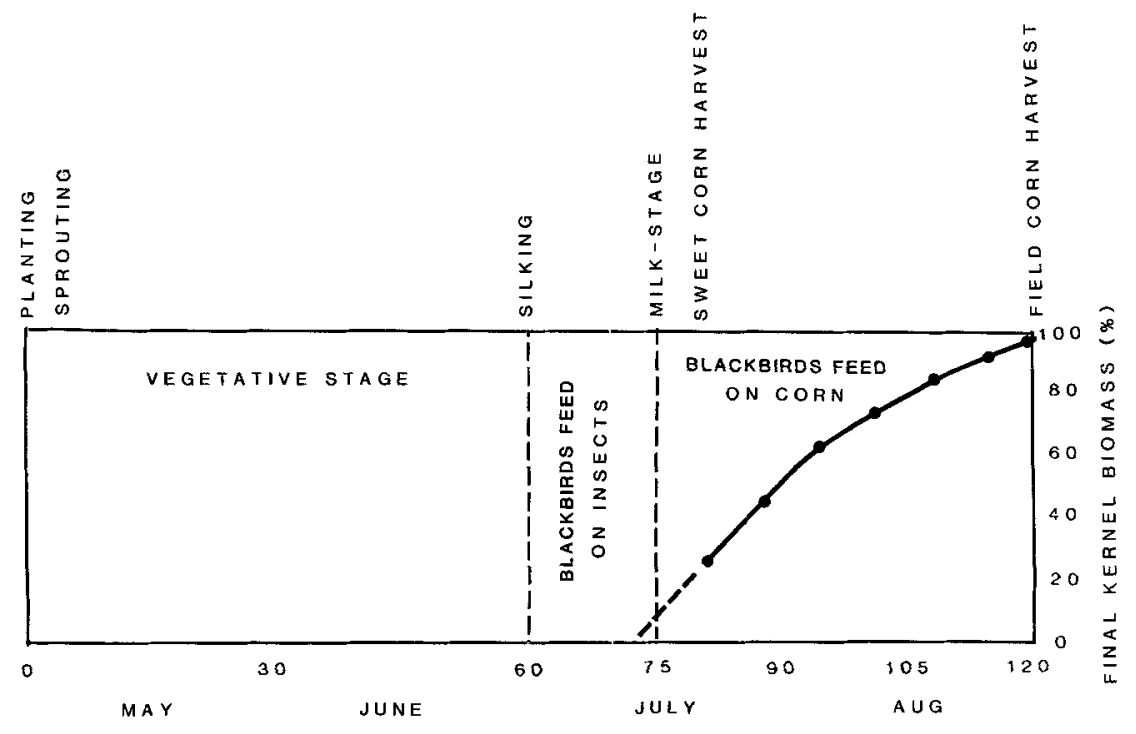

DAYS AFTER PLANTING

Figure 1. Chronology of typical sweet or field corn planting in midwestern United States, showing rate of biomass accumulation in kernels after silking (Woronecki et al. 1980). 
untreated fields with higher insect populations. Subsequent bird damage to sweet corn was also less in these insect-poor fields compared with the untreated fields (Fig. 2).

In another trial, the treatment with insecticide of one area of a sweet corn field infested with European corn borers and rootworm beetles resulted in significantly fewer insects and subsequently less bird damage ( $7 \%$ of ears damaged) than in the untreated area (53\% of ears damaged) (Straub 1989). Red-winged Blackbirds slit open the husks to remove corn borer larvae from infested ears as well as to feed on the milk-stage kernels. A recent aviary and field study also indicated that Red-winged Blackbirds preferred to feed on ears infested with corn ear worms than on insect-free ears (Okurut-Akol 1989).

Other studies confirmed that insects, especially rootworm beetles, were an important food of Red-winged Blackbirds in corn fields during the silking period, comprising over $50 \%$ of the birds' diet (Table 1). There was a strong positive correlation between rootworm beetle density and Red-winged Blackbird numbers among 43 fields of field corn sampled during the silking period, indicating that birds were initially attracted to fields with high densities of insects (Bollinger \& Caslick 1985a). This study also suggested that Red-winged Blackbirds suppressed beetle populations in corn fields near roosts, providing some economic benefit to farmers (Bollinger \& Caslick 1985c).
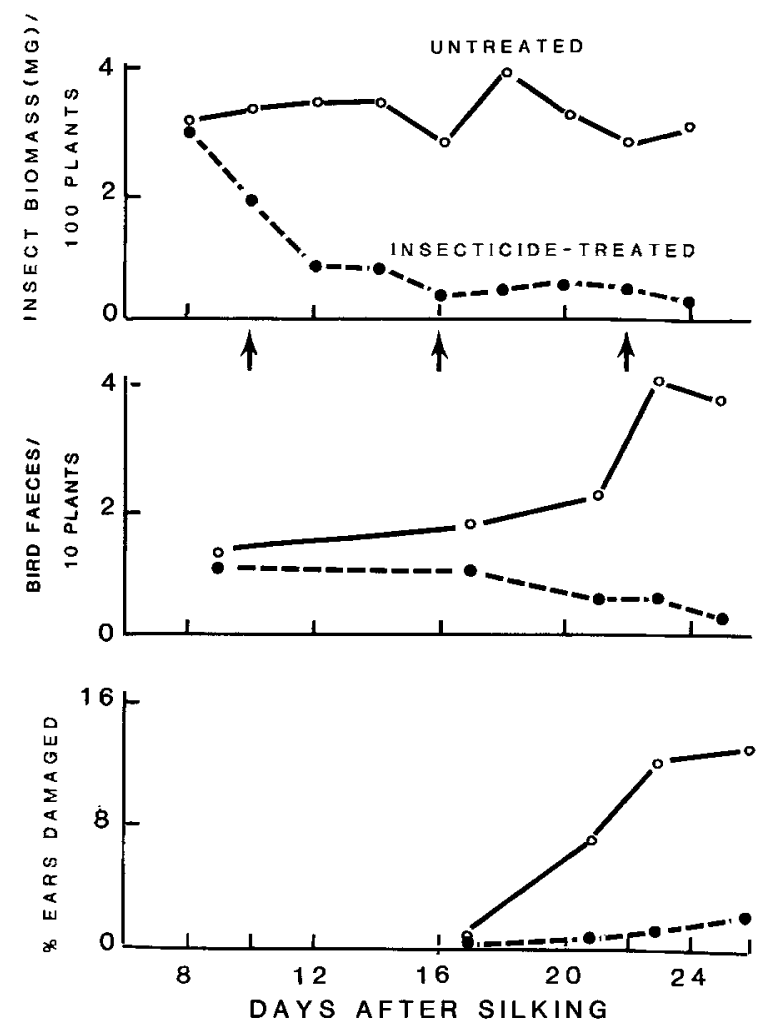

Figure 2. Estimates of insect biomass, bird faeces and Red-winged Blackbird damage per corn plant in eight insecticide-treated and four untreated fields of sweet corn in Ohio, 1978 (data from Woronecki et al. 1981). Arrows refer to dates insecticide was applied. 
Table 1. Food (aggregate \% volume) from Red-winged Blackbirds collected in corn fields during the predamage period and in corn fields (New York) or at a night-time roost (Ohio) during the damage period

\begin{tabular}{|c|c|c|c|c|}
\hline \multirow[b]{2}{*}{ Food } & \multicolumn{2}{|c|}{$\begin{array}{l}\text { Pre-damage (silking) } \\
\text { period }\end{array}$} & \multicolumn{2}{|c|}{$\begin{array}{c}\text { Damage (kernel maturation) } \\
\text { period }\end{array}$} \\
\hline & $\begin{array}{l}\text { New York } \\
\quad(n=21)\end{array}$ & $\begin{array}{l}\text { Ohiob }^{b} \\
(n=17)\end{array}$ & $\begin{array}{c}\text { New York } \\
(n=84)\end{array}$ & $\begin{array}{c}\text { Ohio }^{b} \\
(n=66)\end{array}$ \\
\hline Rootworm beetles & 59 & 33 & 4 & $<1$ \\
\hline Other arthropods & 8 & 35 & 6 & 6 \\
\hline Corn & $19^{\mathrm{c}}$ & $23^{c}$ & 89 & 88 \\
\hline Weed seeds & 0 & 6 & 0 & 5 \\
\hline Other & 14 & 3 & 1 & 1 \\
\hline
\end{tabular}

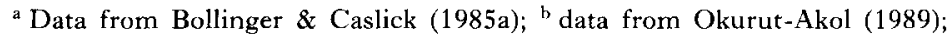

${ }^{\mathfrak{c}}$ mature kernels gleaned off of ground from previous year's harvest.
}

Surprisingly, fields of field corn with high beetle populations and Red-winged Blackbird numbers during the silking period subsequently had no more bird damage to kernels than did fields with low populations of insects (Bollinger $\&$ Caslick 1985b). This differs from the findings in sweet corn and perhaps relates to the contrasting period of time in which birds damage kernels in the two crops. One would expect a high correlation between silking-period bird activity and subsequent damage to kernels in sweet corn because damage can occur for only a few days after the kernels enter the milk stage of development before harvest occurs. In contrast, field corn is damaged by birds for an additional 20-40 days before harvest (Fig. 1). Therefore, as the kernels ripened and became the prime attractant, birds may have gradually spilled over into and fed on corn in fields with fewer insects, lessening the correlation between initial field attractiveness due to insects and final damage to kernels.

\section{Feeding during kernel maturation period}

At the end of the silking period when kernels enter the milk stage, feeding by Redwinged Blackbirds on insects declines sharply as the birds switch to corn (Table 1). Whether this switch is because corn is preferred to insects, or because corn simply provides a greater energy intake per unit of time and effort, is unknown. However, once Red-winged Blackbirds start feeding on corn, both aviary and field studies have shown that most damage (kernels eaten) usually occurs during the milk and early dough stage of kernel development (20-30 DAS), declining thereafter (Bridgeland 1979, Bollinger 1983, Dolbeer et al. 1984). For example, in a controlled aviary study with field corn, birds damaged three times as many kernels per ear at 16-20 DAS as they did at 40 DAS (Fig. 3). However, this should not be construed as demonstrating that Red-winged Blackbirds prefer kernels in the early stages of maturity. Field corn kernels contain only about $25 \%$ of their final biomass at 20 days after silking compared with $70 \%$ at 40 days (Fig. 1). Thus, a bird must eat about three times as many kernels at 20 DAS as at 40 DAS to obtain the same corn biomass. Although mean percent damage per bird declined steadily after day 20 in this aviary study, the mean biomass consumed remained constant (Fig. 3). The birds apparently adjusted their rate of damage to reflect the biomass content of the kernels, and not to reflect a preference for corn at a particular stage of maturity.

One obvious management implication for sweet corn is that the timing of harvest 


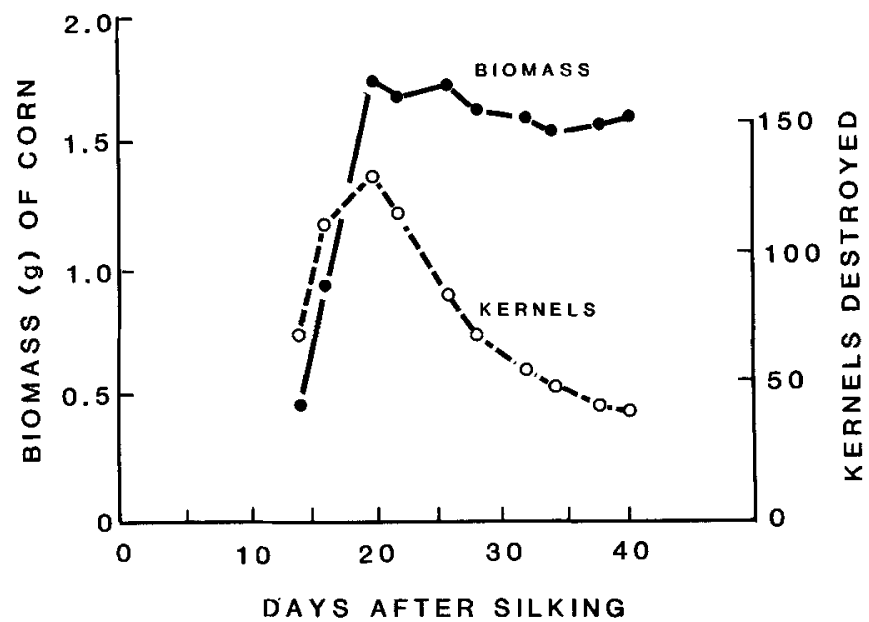

Figure 3. Dry-weight biomass of field corn eaten and number of kernels destroyed per individual Redwinged Blackbird per six hours in an aviary (Dolbeer et al. 1984).

can have a dramatic influence on the level of bird damage. Damage can increase rapidly once kernels enter the vulnerable milk stage, so that advancement of harvest by only one or two days can result in substantially less damage (Fig. 4), especially if combined with insect control in the silking period to reduce the initial attractiveness of sweet corn fields to birds.

For field corn, where damage occurs over a much longer period of kernel development, the adjustment of harvest date is less effective in reducing damage. Furthermore, Red-winged Blackbird feeding activity on insects during the silking period may not be related to final damage. Thus, management programmes to reduce

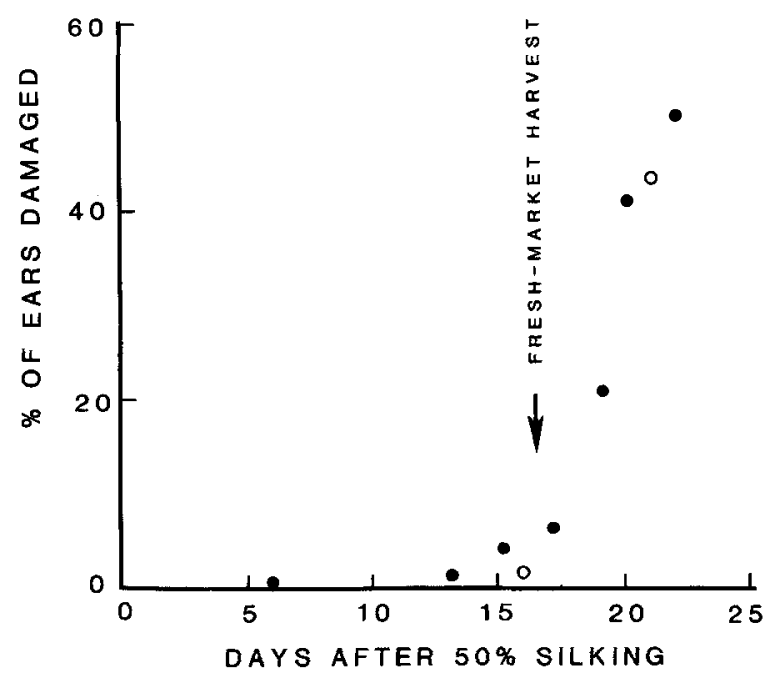

Figure 4. Red-winged Blackbird damage to sweet corn in relation to number of days after $50 \%$ of plants silk. The solid circles refer to mean damage values for two fields sampled on seven dates in 1977 (Dolbeer 1980); the open circles to four fields sampled on two dates in 1975 (Stickley \& Ingram 1976). 
insect numbers in field corn may not necessarily reduce subsequent bird damage. In fact, Red-winged Blackbird feeding activity in silking-stage field corn should be viewed as beneficial, and management activities to keep birds out of field corn should not be implemented until the corn enters the milk stage and is vulnerable to bird damage. Once field corn enters the milk stage, protective measures to reduce damage (to be discussed below) are more critical in the early stages of kernel development (i.e. 18-30 DAS) than later, because the damage potential is much higher at this time. In addition, bird damage during the early maturational stages is more likely to lead to secondary damage (fungal, insect, sprouting) of kernels than is damage at later stages (Woronecki et al. 1980). Thus, bird numbers being equal, a farmer will obtain a greater return from his efforts by protecting field corn from feeding flocks during the milk stage of maturity than during later stages.

\section{Cultivar resistance to reduce damage}

An ideal resolution of the conflict between corn farmers and Red-winged Blackbirds would be to couple the beneficial feeding habits of the birds in silking-stage corn, as outlined above, with management techniques to reduce substantially the damage by Red-winged Blackbirds once the corn enters the milk stage. One promising means of reducing bird damage to corn is through the use of cultivars resistant to attack by birds. While this concept has been considered since at least the 1950s (Anon. 1952, Thompson 1963, Linehan 1977), little progress was made until aviary testing of cultivars was initiated in the 1980 s (Woronecki et al. 1987).

\section{Free-choice $v s$ no-choice tests}

Our field station has conducted various aviary tests encompassing over 60 sweet and field corn cultivars under free-choice (up to eight cultivars presented to birds at same time) and no-choice (only one cultivar presented with no alternative food) regimes. Cultivars differed substantially in susceptibility to damage under free-choice regimes with certain cultivars being virtually untouched by birds. Under no-choice regimes significant differences in damage among cultivars persist, although the differences are not nearly as extreme as in free-choice tests ('Tables 2,3). No cultivar has been completely resistant to damage under the no-choice regime. However, certain cultivars do have consistently less damage than others, even in a no-choice regime that is more severe than field situations where birds would always have alternative food sources such as weed seeds and insects. As a corollary, management of the habitat within the birds' foraging range surrounding roosts to provide alternative feeding areas should enhance the effectiveness of resistant cultivars. This will be discussed more fully below.

\section{Correlation of cultivar characteristics with damage}

Husk coverage of the ear, expressed by total husk weight, husk weight beyond the cob tip or length of husk extension beyond the cob tip, has been the characteristic most strongly correlated (negatively) with damage, explaining up to $60 \%$ of the variation in damage among cultivars in aviary tests (Fig. 5). This pattern held both in tests in which characteristics were measured on the specific ears placed in cages with birds (Dolbeer et al. 1982, 1988) and in tests where characteristics were measured in an independent sample of ears from the same population as the ears selected for the cages (Dolbeer et al. 1984, 1986a). Weatherhead and Tinker (1983) noted that 
Table 2. Ranking of eight cultivars of field corn for damage (\% of kernels eaten) by Red-winged Blackbirds in aviary tests under free-choice and no-choice regimes, 1980-81 (Dolbeer et al. 1984)

\begin{tabular}{|c|c|c|c|c|}
\hline \multirow[b]{2}{*}{ Rank } & \multicolumn{2}{|c|}{ Free-choice test } & \multicolumn{2}{|c|}{ No-choice test } \\
\hline & Cultivar & Damage $^{a}$ & Cultivar & Damage $^{a}$ \\
\hline 1 & 7 & $0.5 \mathrm{a}$ & 7 & $4 \cdot 7$ a \\
\hline 2 & 3 & $0.9 \mathrm{ab}$ & 3 & $4.9 \mathrm{a}$ \\
\hline 3 & 6 & $2 \cdot 0 \mathrm{ab}$ & 2 & $6 \cdot 0 \mathrm{ab}$ \\
\hline 4 & 5 & $2 \cdot 1 \mathrm{ab}$ & 5 & $6.6 \mathrm{bc}$ \\
\hline 5 & 8 & $3.4 \mathrm{abc}$ & 6 & $6.9 \mathrm{bc}$ \\
\hline 6 & 9 & $4 \cdot 2 \mathrm{bc}$ & 8 & $7.0 \mathrm{bc}$ \\
\hline 7 & 2 & $5 \cdot 8 \mathrm{c}$ & 9 & $7.6 \mathrm{bc}$ \\
\hline 8 & 10 & $14.9 \mathrm{~d}$ & 10 & $8 \cdot 1 \mathrm{c}$ \\
\hline
\end{tabular}

a Means with different letters are significantly $(P<0.05)$ different, Duncan's Multiple Range Test.

Table 3. Ranking of cultivars of sweet corn for percent of ears damaged by Red-winged Blackbirds in two nochoice aviary tests and in a field test in Ohio (Dolbeer et al. 1988)

\begin{tabular}{|c|c|c|c|c|c|c|}
\hline \multirow[b]{3}{*}{ Rank } & \multicolumn{6}{|c|}{ Ears damaged by birds $(\%)$} \\
\hline & \multicolumn{2}{|c|}{1985 Aviary test } & \multicolumn{2}{|c|}{1986 Aviary test } & \multicolumn{2}{|c|}{1986 Field test } \\
\hline & Cultivar & Damage $^{a}$ & Cultivar & Damage $^{a}$ & Cultivar & Damage $^{\mathbf{a}}$ \\
\hline 1 & 22 & $31 a$ & 22 & $38 \mathrm{a}$ & 22 & $16 \mathrm{a}$ \\
\hline 2 & 18 & $36 a$ & 27 & $41 \mathrm{ab}$ & 27 & $21 \mathrm{a}$ \\
\hline 3 & 31 & $42 \mathrm{ab}$ & 16 & $56 \mathrm{abc}$ & 18 & $42 \mathrm{~b}$ \\
\hline 4 & 6 & $45 \mathrm{abc}$ & 18 & 63 abc & 16 & $50 \mathrm{~b}$ \\
\hline 5 & 32 & $52 \mathrm{bc}$ & 34 & $69 \mathrm{bcd}$ & 19 & $54 \mathrm{~b}$ \\
\hline 6 & 15 & $56 \mathrm{bcd}$ & 35 & $69 \mathrm{bcd}$ & 23 & $76 \mathrm{c}$ \\
\hline 7 & 16 & $58 \mathrm{cde}$ & 19 & $75 \mathrm{~cd}$ & & \\
\hline 8 & 19 & 59 cde & 23 & $97 \mathrm{~d}$ & & \\
\hline 9 & 13 & 64 def & & & & \\
\hline 10 & 25 & $72 \mathrm{ef}$ & & & & \\
\hline 11 & 23 & $78 \mathrm{f}$ & & & & \\
\hline
\end{tabular}

a Means with different letters are significantly $(P<0 \cdot 05)$ different, Duncan's Multiple Range Test.

cultivars with an extended period of vulnerability due to variation in maturity among plants were likely to have greater total losses to birds than cultivars with highly synchronized ear development among plants (i.e. in which all ears pass through the vulnerable milk stage at the same time).

\section{Comparison of aviary and field results: influence of kernel maturity}

Field evaluations of cultivars in areas of high bird numbers have generally supported aviary results. For example, in 1982 eight cultivars of field corn were evaluated in a 


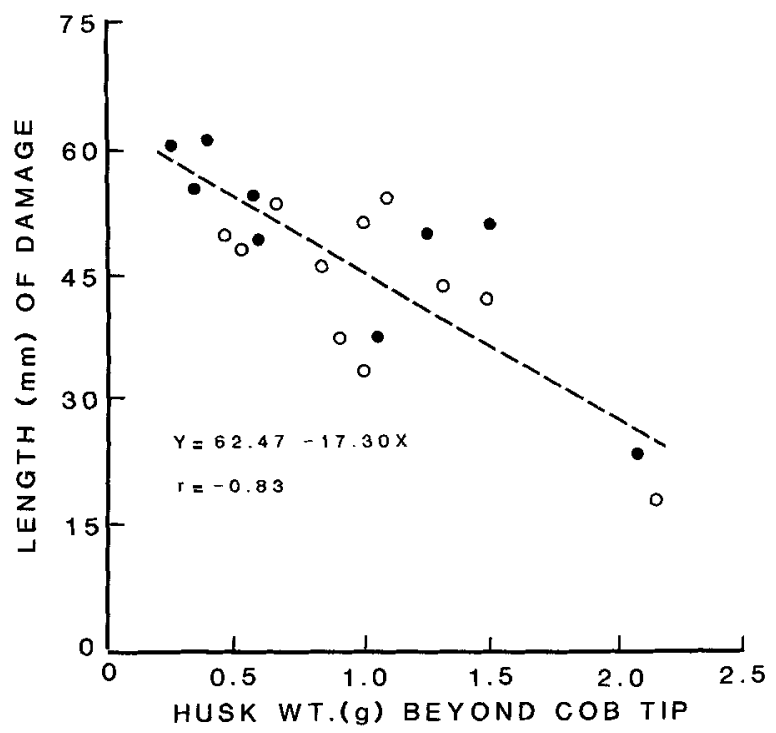

Figure 5. Relation of mean husk weight beyond cob tip to mean damage by Red-winged Blackbirds for 11 (1985, open circles) and eight (1986, solid circles) cultivars of sweet corn in no-choice aviary tests (Dolbeer et al. 1988).

free-choice aviary test and in a field test within $2 \mathrm{~km}$ of a roost containing 100,000 Red-winged Blackbirds. With one exception (Cultivar 10), the ranking of cultivars for damage was similar in the aviary and field tests (Table 4). The low level of damage for Cultivar 10 in the field test was probably related to its stage of maturity when damage occurred, as discussed below.

Stage of kernel maturity at the time of damage by Red-winged Blackbirds can have a major influence on the relative resistance of field corn cultivars. For example, in no-choice aviary tests Cultivar 10 had 1.5 to 4 times the damage of Cultivar 7 at 1425 DAS. However, from 30 to $50 \mathrm{DAS}$, these two cultivars had virtually no difference in damage (Fig. 6). This interaction of maturity and relative resistance is perhaps explained by the fact that the birds could penetrate the husk farther below the ear tip to gain access to kernels during the milk stage on a thin, short-husked cultivar such as Cultivar 10 compared to Cultivar 7 . As the kernels matured, the birds had to penetrate an increasingly shorter distance down the husk to obtain adequate biomass. Thus, differences between the two cultivars became less pronounced at later stages of kernel maturity. Because Cultivar 10 was the earliest maturing cultivar in the above described field test ('Table 4), it may have passed through the most vulnerable stage and escaped significant damage (Weatherhead and Tinker 1983) before Red-winged Blackbirds began feeding on milk-stage kernels of the other seven cultivars.

In another field evaluation of aviary results for field corn, eight farmers were provided with seed for Cultivars 3 and 8 (a resistant and susceptible cultivar, respectively, based on 1982 aviary tests-Table 4). The farmers planted these cultivars side by side in 1983 in 15 fields in localities where they considered blackbirds a problem. Damage was assessed at harvest and the results supported aviary findings. Cultivar 3 had significantly $(P<0.05)$ less loss $(3.3 \%)$ and ears damaged $(32 \%)$ than did Cultivar $8(6.7 \%$ and $55 \%$, respectively) (Dolbeer et al. 1986b). 
Table 4. Ranking of eight cultivars of field corn for damage ( $\%$ of kernels eaten) by Red-winged Blackbirds in aviary and field tests in Ohio, 1982 (Woronecki et al. 1987)

\begin{tabular}{lccccc}
\hline & \multicolumn{2}{c}{ Free-choice aviary test } & & \multicolumn{2}{c}{ Free-choice field test } \\
\cline { 2 - 3 } \cline { 5 - 6 } Rank & Cultivar & Damage $^{\mathrm{a}}$ & & Cultivar & Damage $^{\mathrm{a}}$ \\
\hline 1 & 7 & $1.8 \mathrm{a}$ & & 7 & $9.1 \mathrm{a}$ \\
2 & 3 & $3.5 \mathrm{a}$ & & 9 & $9.5 \mathrm{a}$ \\
3 & 5 & $4.2 \mathrm{a}$ & & 5 & $10.6 \mathrm{a}$ \\
4 & 9 & $4.2 \mathrm{a}$ & & 10 & $11.3 \mathrm{a}$ \\
5 & 6 & $8.4 \mathrm{~b}$ & & 3 & $11.4 \mathrm{a}$ \\
6 & 2 & $10.9 \mathrm{~b}$ & & 6 & $15.2 \mathrm{~b}$ \\
7 & 8 & $11.1 \mathrm{~b}$ & & 2 & $17.6 \mathrm{~b}$ \\
8 & 10 & $16.3 \mathrm{c}$ & 8 & $21.8 \mathrm{c}$ \\
\hline
\end{tabular}

a Means with different letters are significantly $(P<0 \cdot 05)$ different, Duncan's Multiple Range Test.

In 1985 and 1986 sweet corn cultivars were evaluated for resistance to bird damage in aviary and field tests. The use of resistant cultivars seemed particularly well-suited for sweet corn because of the above-described findings that differences in resistance among cultivars of field corn were maximum at 15-20 DAS (Fig. 6). This is precisely the time sweet corn is vulnerable to damage immediately before harvest. Each of 11 sweet corn cultivars was presented to Red-winged Blackbirds in the aviary under no-choice conditions in 1985 . This evaluation was repeated in 1986 with eight cultivars. In both years there were consistent, significant differences in damage among cultivars with the most susceptible cultivar receiving about $2 \cdot 5$ times more damage than the least susceptible (Table 3). Six of the cultivars were then evaluated in 1986 in a field test within $2 \mathrm{~km}$ of a roost containing over 30,000 Redwinged Blackbirds. The ranking of the cultivars was almost identical to that found in the aviary and the differences in damage among cultivars were even greater; the most- and least-resistant cultivars had 16 and $76 \%$ of the ears damaged, respectively (Table 3).

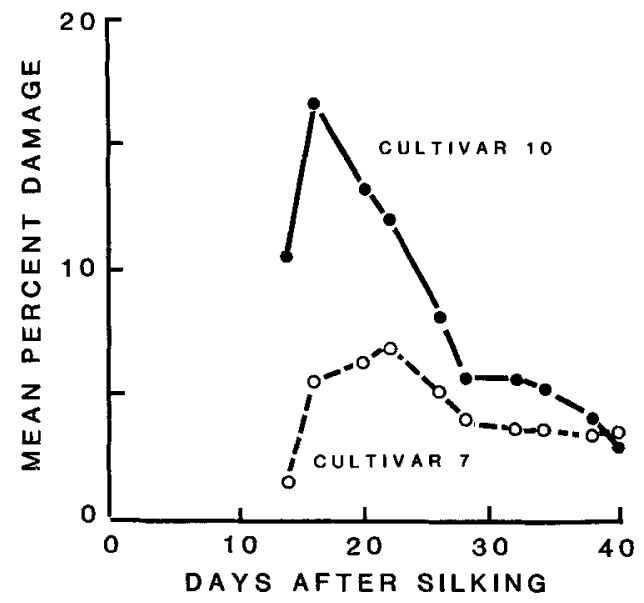

Figure 6. Mean percent damage by Red-winged Blackbirds in relation to silking date for two cultivars of field corn in an aviary, 1981 (Dolbeer et al. 1984). 


\section{Rating commercial cultivars for resistance}

Results of the above tests suggest that cultivar resistance has the potential for reducing the amount of bird damage to ripening corn. However, if bird-resistant cultivars are to serve a useful role in integrated pest management programmes for corn, they must be competitive with the cultivars that farmers already grow (Dolbeer et al. 1986b). Because the number of farmers affected by economically significant bird damage is small, it is unlikely that commercial seed companies will invest to produce special bird-resistant cultivars. An alternative is to develop a bird-resistance rating system for commercial corn cultivars based on the husk characteristics known to be correlated with bird damage. This would allow large numbers of cultivars (which are already evaluated for various agronomic characteristics annually in performance tests at agricultural experiment stations) to be inexpensively and objectively rated for their predicted resistance to bird damage. Then, farmers in high-damage areas could include bird resistance along with other characteristics normally considered in selecting a cultivar for a particular situation.

To evaluate such a rating system, Dolbeer $\&$ Woronecki (unpubl. data) measured husk extension weight for a sample of 12 ears from each of 229 field corn cultivars grown in a performance test in 1987 and ranked these cultivars for potential resistance to bird damage. Overall, 35 of the 229 cultivars had mean husk extension weights $>2.0 \mathrm{~g}$, considered likely to be resistant (Fig. 5), and 56 had weights $<1.0 \mathrm{~g}$, considered likely to be susceptible.

Three cultivars from the ten predicted to be most resistant, three cultivars from the ten predicted to be least resistant and two intermediate cultivars were evaluated in a free-choice aviary test with Red-winged Blackbirds in 1988. The results supported the simple ranking system. The three 'predicted resistant' cultivars averaged $2.5 \%$ corn loss, significantly $(P<0.05)$ less than the $26.1 \%$ loss for the three 'predicted susceptible' cultivars. The two intermediate cultivars had intermediate damage levels.

\section{Bird frightening techniques to reduce damage}

Conventional bird-frightening techniques, such as propane exploders, hawk kites, shooting, reflective ribbons, and the chemical 4-aminopyridine, can all be of assistance in reducing Red-winged Blackbird damage to corn (Dolbeer 1980, Conover 1984). The deployment of these devices when the corn is most vulnerable to damage, as discussed above, is critical to their success. Their effectiveness should also be enhanced when used in fields of resistant cultivars. One caveat in the use of frightening techniques is that labour and material costs for their proper deployment are often relatively high, and careful assessment of expected benefits in relation to these costs is needed before deployment (Dolbeer 1981, Conover 1984).

\section{Alternative foods}

Means of reducing Red-winged Blackbird damage to corn discussed above include insect management, resistant cultivars, and proper timing in the deployment of frightening devices and in harvest (for sweet corn). The final component of an integrated pest management programme involves the provision of alternative foods outside the corn fields but within the birds' daily foraging range from the roost. The provision of alternative food in late summer is intended only to aid in the temporary diversion of Red-winged Blackbirds from ripening corn. It is not intended to 
increase the overall attractiveness of an area to Red-winged Blackbirds nor to enhance the survival rate of individuals in the population. Food does not appear to be as critical or limiting a factor for Red-winged Blackbirds in late summer as it is in spring and early summer (Clark et al. 1986). The basic tenet presented here is that if birds are to be discouraged from feeding in corn fields once kernels enter the milk stage, alternative feeding sites must be available. This hypothesis is supported by a field study where blackbird damage to corn was highest in areas of least agricultural diversity (Stone \& Danner 1980).

Fortunately, there are numerous opportunities for providing alternative feeding areas in late summer. For example, oats and wheat are typically harvested at the time corn enters the silking stage. Delayed ploughing of oat and wheat stubble until after the corn harvest will permit Red-winged Blackbirds to feed on the waste grains (Hintz \& Dyer 1970, McNicol et al. 1982), and should reduce feeding pressure on corn. Delayed ploughing of early-harvested sweet corn fields can also serve this purpose. The provision of natural and planted plots of wildlife food crops on wildlife refuges and on areas of farms set aside in price-support programmes should also be beneficial. Such 'lure crops' have been used for years in North America to reduce waterfowl damage to maturing small-grain crops (Knittle \& Porter 1988). Such plantings also have shown promise for reducing Red-winged Blackbird damage to nearby commercial sunflower fields (Cummings et al. 1987).

\section{Conclusions}

Red-winged Blackbirds will continue to be a dominant part of the avifauna of North America and there will be conflicts with agriculture as long as healthy, productive wetlands are maintained alongside agricultural lands. My thesis is that these conflicts are not irreconcilable. Substantial progress has been made in finding ways to accommodate these birds as a part of the wetland and agricultural ecosystemsusing them to help control insect pests while simultaneously managing corn in ways to reduce bird damage to tolerable levels. Management techniques include birdresistant cultivars, insect management in corn fields, proper timing in the deployment of frightening devices, the provision of alternative feeding areas and harvest at the earliest possible date. None of these techniques used alone will be sufficient; success will be achieved when they are used together in a coordinated programme. This is integrated pest management in the truest sense of the term. Much work needs to be done, especially in refining estimates of costs and benefits associated with birds feeding in corn fields and in the further refinement of various control strategies. However, important steps have been taken in achieving this goal and the future for resolving blackbird-agricultural conflicts appears bright.

Many colleagues within the US Department of Agriculture and various US and Canadian universities have contributed ideas and data discussed in this paper. In particular, I recognize E. K. Bollinger, R. G. Clark, R. A. Stehn, P. J. Weatherhead and P. P. Woronecki.

\section{References}

Anonymous 1952. Bird damage to corn. Ohio Farm and Home Res. 37(279): 87, 96.

Anonymous 1983. Senate Committee Bird Concern. The Sunflower 9(8): 4.

Bendell, B.E., \& Weatherhead, P.J. 1982. Prey characteristics of upland-breeding Red-winged Blackbirds, Agelaius phoeniceus. Can. Field-Nat. 96: 265-271.

Bendell, B.E., Weatherhead, P.J. \& Stewart, R.K. 1981. The impact of predation of Red-winged Blackbirds on European corn borer populations. Can. J. Zool. 59: 1535-1538. 
BESSER, J.F. \& BraDy, D.J. 1986. Bird damage to ripening field corn increases in the United States from 1971 to 1981 . Fish and Wildl. Leafl. 7. US Fish \& Wildlife Service.

Bollinger, E.K. 1983. Phenology of Red-winged Blackbird use of field corn in central New York. Proc. East. Wildl. Damage Control Conf. 1: 265-270.

Bollinger, E.K. \& CASLICK, J.W. 1985a. Red-winged Blackbird predation on northern corn rootworm beetles in field corn. J. Appl. Ecol. 22: 39-48.

Bollinger, E.K. \& Caslick, J.W. 1985b. Factors influencing blackbird damage to field corn. J. Wildl. Mgmt. 49: 1109-1115.

Bollinger, E.K. \& CAslick, J.W. 1985c. Northern corn rootworm beetle densities near a Red-winged Blackbird roost. Can. J. Zool. 63: 502-505.

Bridgeland, W.T. 1979. Timing bird control applications in ripening corn. Proc. Bird Control Semin. 8: $222-228$.

Clark, R.G., Weatherhead, P.J., Greenwood, H. \& Titman, R.D. 1986. Numerical responses of redwinged blackbird populations to changes in regional land-use patterns. Can. J. Zool. 64: 1944-1950.

Conover, M.R. 1984. Comparative effectiveness of Avitrol, exploders, and hawk-kites in reducing blackbird damage to corn. J. Wildl. Mgmt. 48: 109-116.

Cummings, J.L., Guarino, J.L., Knittle, C.E. \& Royall, W.C., Jr. 1987. Decoy plantings for reducing blackbird damage to nearby commercial sunflower fields. Crop Prot. 6: 56-60.

DolbeER, R.A. 1980. Blackbirds and corn in Ohio. US Fish Wildl. Serv., Resour. Publ. 136.

DolbeER, R.A. 1981. Cost-benefit determination of blackbird damage control for cornfields. Wildl. Soc. Bull. 9: 43-50.

Dolbeer, R.A. 1982. Migration patterns for age and sex classes of blackbirds and starlings. J. Field Ornithol. 53: 28-46.

DolbeER, R.A. 1986. Current status and potential of lethal means of reducing bird damage in agriculture. Proc. Int. Orn. Congr. XIX: 474-483.

Dolbeer, R.A. \& Stehn, R.A. 1983. Population status of blackbirds and starlings in North America, 1966-1981. Proc. East. Wildl. Damage Control Conf. 1: 51-61.

Dolbeer, R.A., Ingram, C.R. \& Seubert, J.L. 1976. Modeling as a management tool for assessing the impact of blackbird control. Proc. Vertebr. Pest Conf. 7: 35-45.

Dolbeer, R.A., Woronecki, P.P. \& Mason, J.R. 1988. Aviary and field evaluations of sweet corn resistant to damage by blackbirds. J. Amer. Soc. Hort. Sci. 113: 460-464.

Dolbeer, R.A., Woronecki, P.P. \& Stehn, R.A. 1982. Effect of husk and ear characteristics on resistance of maize to blackbird (Agelaius phoeniceus) damage in Ohio, USA. Prot. Ecol. 4: 127-139.

Dolbeer, R.A., Woronecki, P.P. \& SteHn, R.A. 1984. Blackbird (Agelaius phoeniceus) damage to maize: crop phenology and hybrid resistance. Prot. Ecol. 7: 43-63.

DolbeEr, R.A., Woronecki, P.P. \& STEHN, R.A. 1986a. Resistance of sweet corn to damage by blackbirds and starlings. ]. Amer. Soc. Hort. Sci. 111: 306-311.

Dolbeer, R.A., Woronecki, P.P. \& STehn, R.A. 1986b. Blackbird-resistant hybrid corn reduces damage but does not increase yield. Wildl. Soc. Bull. 14: 298-301.

Hintz, J.V. \& Dyer, M.I. 1970. Daily rhythm and seasonal change in the summer diet of adult redwinged blackbirds. J. Wildl. Mgmt. 34: 789-799.

Kleingartner, L. 1989. Blackbird controls still on front burner. The Sunflower 15(3): 32-33.

KNitTle, C.J. \& Porter, R.D. 1988. Waterfowl damage and control methods in ripening grain: an overview. US Dept. Int. Fish and Wildl. Serv., Fish and Wildl. Tech. Rep. 14.

Linehan, J.T. 1977. Resistance to bird attack in 265 field corn hybrids. Proc. Northeast. Corn Improvement Conf. 32: 19-31.

Martin, M.L. 1977. Flocking and roosting activities of the Red-winged Blackbird in southern Quebec. Unpubl. M.S. thesis, Macdonald College of McGill University, Montreal.

McNicol, D.K., Robertson, R.J. \& Weatherhead, P.J. 1982. Seasonal, habitat, and sex-specific food habits of Red-winged Blackbirds: implications for agriculture. Can. J. Zool. 60: 3282-3289.

Meanley, B. \& Royall, W.C. Jr. 1976. Nationwide estimates of blackbirds and starlings. Proc. Bird Control Semin. 7: 39-40.

MeAnley, B. \& WebB, J.S. 1965. Nationwide population estimates of blackbirds and starlings. Atlantic Nat. 20: 189-191.

Motт, D.F. \& Stone, C.P. 1973. Predation on corn earworms by Red-winged Blackbirds. The Murrelet 54: $8-10$.

OKuRUT-Akol, F.H. 1989. Relations among blackbird corn damage, pest insects and insecticide applications. Unpubl. M.S. thesis. Colorado State University, Fort Collins.

Schorger, A.W. 1973. The Passenger Pigeon: Its Natural History and Extinction. Norman: University of Oklahoma Press. 
Stickley, A.R., Jr. \& Ingram, C.R. 1976. Methiocarb as a bird repellent for mature sweet corn. Proc. Bird Control Semin. 7: 228-238.

Stone, C.P. \& DANNER, C.R. 1980. Autumn flocking of Red-winged Blackbirds in relation to agricultural variables. Am. Midl. Nat. 103: 196-199.

Stone, W.B., Overman, S.R. \& OKoniewski, J.C. 1984. Intentional poisoning of birds with parathion. Condor 86: 333-336.

Straub, R.W. 1989. Red-winged Blackbird damage to sweet corn in relation to infestations of European corn borer (Lepidoptera: Pyralidae). J. Econ. Entomol. 82: 1406-1410.

Thompson, J.M. 1963. Husk extension of field corn in breeding for resistance to bird damage. Unpubl. $\mathrm{PhD}$ thesis, Ohio State University, Columbus.

Tyler, B.M.J. \& Kannenberg, L.W. 1980. Blackbird damage to ripening field corn in Ontario. Can. J. Zool. 58: 469-472.

Weatherhead, P.J. 1982. Assessment, understanding and management of blackbird-agriculture interactions in eastern Canada. Proc. Vert. Pest Conf. 10: 193-196.

Weatherhead, P.J. \& TinkeR, S.H. 1983. Maize ear characteristics affecting vulnerability to damage by red-winged blackbirds. Prot. Ecol. 5: 167-175.

Weatherhead, P.J., Tinker, S.H. \& Greenwood, H. 1982. Indirect assessment of avian damage to agriculture. J. Appl. Ecol. 19: 773-782.

White, S.B., Dolbeer, R.A. \& Bookhout, T.A. 1985. Ecology, bioenergetics, and agricultural impacts of a winter-roosting population of blackbirds and starlings. Wildl. Monogr. 93. $42 \mathrm{pp}$.

WIENS, J.A. \& DYER, M.I. 1975. Simulation modelling of Red-winged Blackbird impact on grain crops. J. Appl. Ecol. 12: 63-82.

Woronecki, P.P., DolbeER, R.A. \& OTIS, D.L. 1987. Evaluating corn varieties for resistance to damage by blackbirds and starlings. In Bullard, R.W. \& Shumake, S.A. (eds) Vertebrate Pest Control and Management. Vol. 5; Materials: 27-38. Philadelphia: American Society for Testing and Materials.

Woronecki, P.P., Dolbeer, R.A. \& Stehn, R.A. 1981. Response of blackbirds to Mesurol and Sevin applications on sweet corn. J. Wildl. Mgmt. 45: 693-701.

Woronecki, P.P., Stehn, R.A. \& Dolbeer, R.A. 1980. Compensatory response of maturing corn kernels following simulated damage by birds. J. Appl. Ecol. 17: 737-746. 